\title{
Vèjo energijos panaudojimo šilumos gamybai, taikant hidraulinę sistemą, tyrimas
}

\section{Jurgita Černeckienè,}

\section{Tadas Ždankus}

Kauno technologijos universitetas, Statybos ir architektūros fakultetas, Pastatu energiniu sistemu katedra, Studentu g. 48-437A

LT-51367 Kaunas

El.paštastadas.zdankus@ktu.lt

\begin{abstract}
Vejo energiją naudojant pastatams šildyti galima ženkliai sumažinti kuro sąnaudas, o tuo pačiu ir aplinkos taršą. Vèjo mechaninès energijos transformavimas ị šilumą nèra naujové, tačiau dabar labiausiai paplitusios elektrinès sistemos, kai vèjaratis suka elektros generatorių, o šiluma pastate gaunama naudojant elektrinius šildytuvus. Daugiau generuojamos šilumos ir mažesnes investicijas galima būtų pasiekti vietoje elektrinès naudojant hidraulinę šilumos generavimo sistemą.

Eksperimentinių tyrimų stende hidraulinès sistemos pagrindinès dalys buvo: krumpliaratinis siurblys, reguliuojamasis ventilis-apkrova ir šilumokaitis. Eksperimentiškai modeliuojama maža vèjo jëgainè su vèjaračio sukimosi dažniu iki $5 \mathrm{~Hz}$. Eksperimentinių tyrimų metu nustatyta, kad hidraulinè šilumos generavimo sistema net ir neapkrauta pasiekia naudingumo koeficientą iki 0,5, o su apkrova efektyvumas išauga iki $>0,85$. Vejo energija sugeneruotą šilumą šilumnešiui galima atiduoti akumuliacinèje talpoje, jei pastate kaip pagrindinis energijos šaltinis naudojamas dujinis ar kieto kuro katilas. Kitu atveju šilumą galima kaupti grunte, jei pastatams šildyti naudojama geoterminè sistema.
\end{abstract}

Raktažodžiai: vèjo energija, hidraulinė sistema, energijos virsmai, šilumos mainai, pastato šildymas

\section{IVADAS}

Vejjo energijos naudojimas žmonių poreikiams seniai žinomas ir gana plačiai taikytas. Pirmosios žinios apie vejo malūnų darbą Europoje datuojamos IX a., o Lietuvos šaltiniuose jie minimi nuo XIV a. [1]. Vejo energija plačiausiai naudota grūdams malti, lentoms pjauti, vandeniui pumpuoti ir pan., t. y. buvo naudota iš vejo gaunama ir nesudètingomis priemonèmis redukuojama mechaninè energija. Plačiai paplitus elektros energijos tiekimo tinklui, vejo energijos naudojimas buvo primirštas ir atgavo pelnytą demesị tik tada, kai pasaulio bendruomenè suprato, kad iškastinis kuras yra baigtinis, kad jo naudojimas sukelia nepageidaujamą klimato kaitą. Todèl šiomis dienomis jau nestebina vèjo jègainių parkai, EWEA (Europos vejo energijos asociacija) $2013 \mathrm{~m}$. pabaigos duomenimis, pagaminantys 7,8 \% Europai reikalingos elektros energijos. Elektros energijos universalumas nekelia abejonių, todèl savaime suprantama, kodèl sparčiausiai vystoma ši vejjo energijos transformavimo sritis, tačiau inžinierių dèmesị buvo patraukę ir vejjo energijos transformavimo ị šilumą ịrenginiai [2-4]. Statybos inžinerijos srities mokslininkams ši tema yra labai aktuali dèl to, kad, remiantis Europos Sąungos duomenimis, pastatuose sunaudojama $40 \%$ visos sunaudojamos energijos [5] ir ši dalis turi būti mažinama ne tik ją efektyviau naudojant, bet ir 
gaminant daugiau energijos iš atsinaujinančių šaltinių. Lietuvai ir panašias klimatines sąlygas turinčioms šalims vejjo energijos naudojimo šilumos gamybai tyrimai labai aktualūs dar ir dèl panašaus vejo energijos potencialo ir energijos poreikio pastatams šildyti pasiskirstymo per metus [6]. Šios sąlygos leidžia vejjo energiją naudoti iš karto, išvengiant energijos praradimų ją kaupiant, o tai dar viena priežastis, kodèl vejo energijos naudojimo šilumos gamybai tema nagrinètina ir reikalinga.

\section{VĖJO ENERGIJOS NAUDOJIMO ŠILUMOS GAMYBAI TECHNOLOGIJŲ APŽVALGA}

Vertinant vejo energijos naudojimo šildymui technologijas, jas galima struktūriškai sugrupuoti ir suskirstyti (1 pav.).

Šiuo metu norint išnaudoti vejjo energiją pastatams šildyti, tai daroma tiesiogiai patalpose elektrinių šildytuvų pagalba, jiems elektros energija gaminama vejjo jëgainèse [7-9]. Tai atitiktų schemą: „Vejjaratis (mechaninè vejjo energi- ja) - elektros generatorius (mechaninès energijos transformavimas $\mathfrak{i}$ elektros energiją) - elektros energijos akumuliatorius - pastato šildymo sistema (elektros energiją naudojantys šildymo prietaisai - oriniai šildytuvai, tepaliniai radiatoriai, spinduliniai šildytuvai ir t. t.)" (1 pav.). Pagal šią schemą, turint vietinị elektros energijos gamybos irrengini, atsiranda elektros energijos akumuliavimo poreikis dèl vejjo energijos potencialo ir energijos poreikio skirtumų, taip pat poreikis turèti rezervinę pastato šildymo sistemą. Paminèti sprendiniai brangina tokių sistemų diegimą ir daro jas techniškai sudètingesnèmis. Naudojant centralizuotai tiekiamą ir iš vejo energijos gaminamą elektros energiją, energijos akumuliatoriaus ir rezervinio šaltinio funkciją atlieka skirstomieji tinklai ir diversifikuotas elektros energijos gamybos tinklas, sistema veiksminga ir galima, tik tokiu atveju iškyla sistemos efektyvumo įvertinimo klausimas dèl papildomų energijos nuostolių skirstomuosiuose tinkluose.

Dar viena schema, kuri gali būti naudojama vejjo energijai transformuoti: „Vejjaratis - elektros

Elektrinè sistema

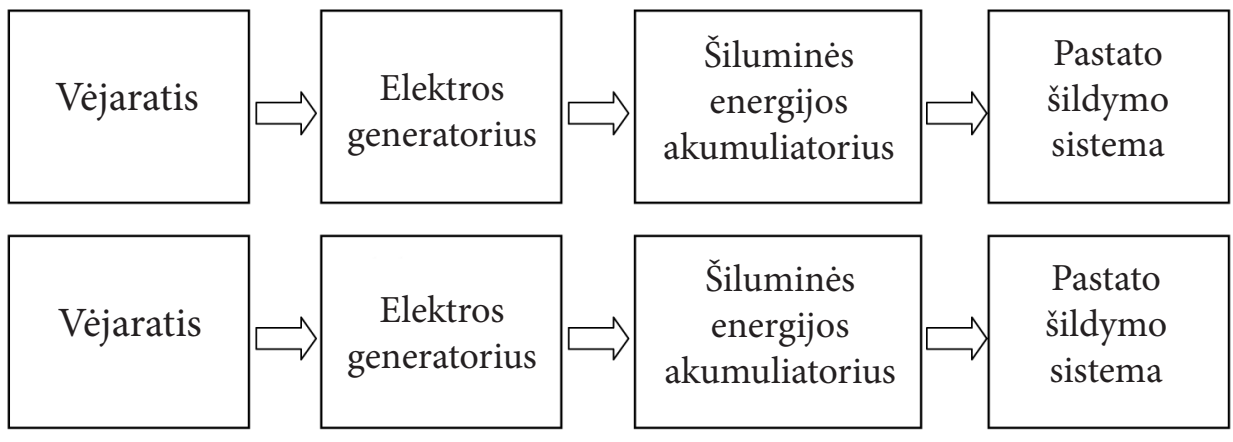

Hidraulinė sistema

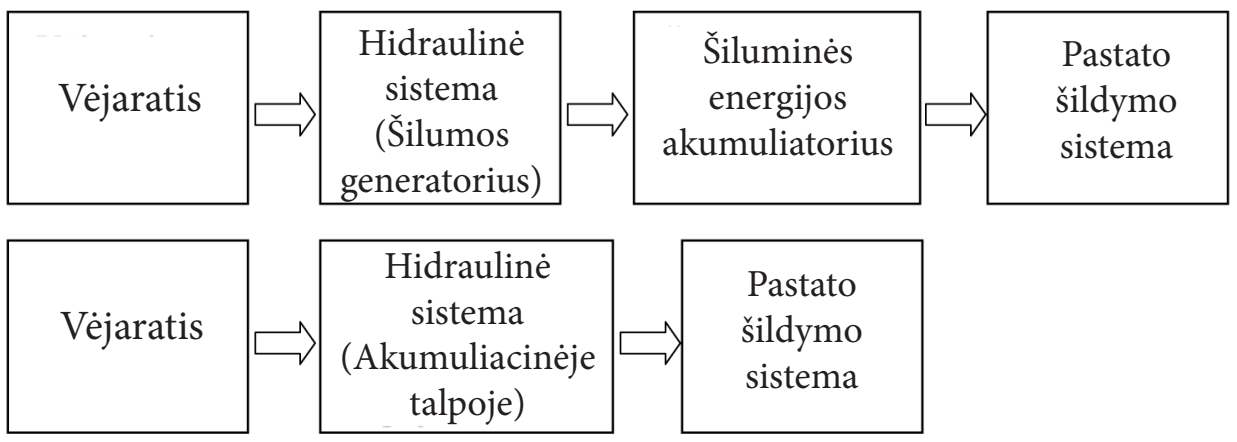

1 pav. Vèjo energijos transformavimo i šilumą sistemų struktūrinės schemos 
generatorius - šiluminès energijos akumuliatorius (vandeniu arba vandens ir neužšąlančių skysčių tirpalu užpildyta talpa) - pastato šildymo sistema (tradicine šildymo sistema, kurios šilumnešis yra vanduo ar jo tirpalai)“. Tokia schema turi privalumą, kad to paties šilumines energijos akumuliatoriams ikrauti galima naudoti papildomus kontūrus, kuriems energiją tieks ir kiti energijos šaltiniai - kietojo arba dujinio kuro katilai, saulès energijos kolektoriai, tam tikrų technologinių i̇renginių aušinimo kontūrai ir pan. Šioje schemoje pastato šildymo sistema bet kuriuo atveju naudojama ta pati ir šios schemos atveju galimas elektros energijos gamybos decentralizavimas.

Vejo energiją galima transformuoti ị šilumą vietoje elektrinès sistemos naudojant hidraulinę $[2,3,10]$. Taikoma schema: „Vejaratis - šilumos generatorius (hidraulinè sistema) - šiluminès energijos akumuliatorius - pastato šildymo sistema“. Nors vejo mechaninès energijos virsmui $\mathfrak{i}$ šilumą, naudojant hidraulinę sistemą (2 pav.) kaip šilumos generatorių, jau yra pasiūlyta nemažai būdų ir metodikų [2-4], šis energijos transformavimo būdas nèra plačiai paplitęs.

Ženklus skysčio temperatūros padidèjimas skysčiui pratekant pro įvairius vožtuvus, droselius, skirstytuvus, dažnai pastebimas hidraulinèse pavarose $[11,12]$. Taip pat ir energetikoje, ruošiantis užkurti vandens ar garo katilą ijjungus maitinimo arba tinklo siurblį, kai vanduo teka uždaru ratu, galima pastebèti, kad vandens temperatūra vien tik dèl recirkuliacijos per trumpą laiko intervalą pakyla keliais laipsniais. Abiem minètais atvejais dèl trinties tarp skysčio dalelių bei skysčio dalelių ir kietų paviršių, o taip pat ir dèl kontakto (skysčio dalelèms keičiant judejimo trajektorijas atsimušus ar aptekant kietus paviršius) su tèkmę ribojančiais paviršiais, skysčio dalelių mechaniné energija virto šilumine, skysčio temperatūra padidejo. Šiais atvejais tai energijos nuostoliai, o hidraulinèse pavarose skysčio temperatūros augimas yra dar ir nepageidaujamas reiškinys - dideja sistemos išsisandarinimo tikimybe, reikia papildomai aušinti alyvą ir pan. [12]. Tačiau abu šie atvejai demonstruoja praktinę galimybę generuoti šilumą praleidžiant skysti pro įvairiausias kliūtis. Kai hidraulinès sistemos energijos šaltinis yra elektros ar vidaus degimo variklis, tokiu būdu generuoti šilumą netikslinga dèl papildomų energijos virsmų, kurie mažina bendrą sistemos efektyvumą. Tada paprasčiau ir efektyviau yra panaudoti elektrinius šildytuvus arba deginti krosnyje kurą. Tačiau kai hidraulinès sistemos energijos šaltinis yra véjas (nieko nekainuojantis), situacija kardinaliai pasikeičia - šilumos gamybai lieka vienas energijos transformavimo procesas - mechaninè energija verčiama šiluma, o tokios sistemos efektyvumas tampa aktualiu tyrimų objektu.

Pirmoji visų minètų schemų (1 pav.) grandis „Vejjaratis“ - tai dažniausiai horizontalios arba vertikalios ašies ịrenginys [7], transformuojantis vẻjo mechaninę energiją i veleno sukamajij judesị. Kai kuriais atvejais vietoje vejjaračio gali būti naudojama mentis arba „burë“, o gaunamas „išejjime" judesys gali būti slenkamasis (svyruojantis), sukamasis arba slenkamasis ir sukamasis.

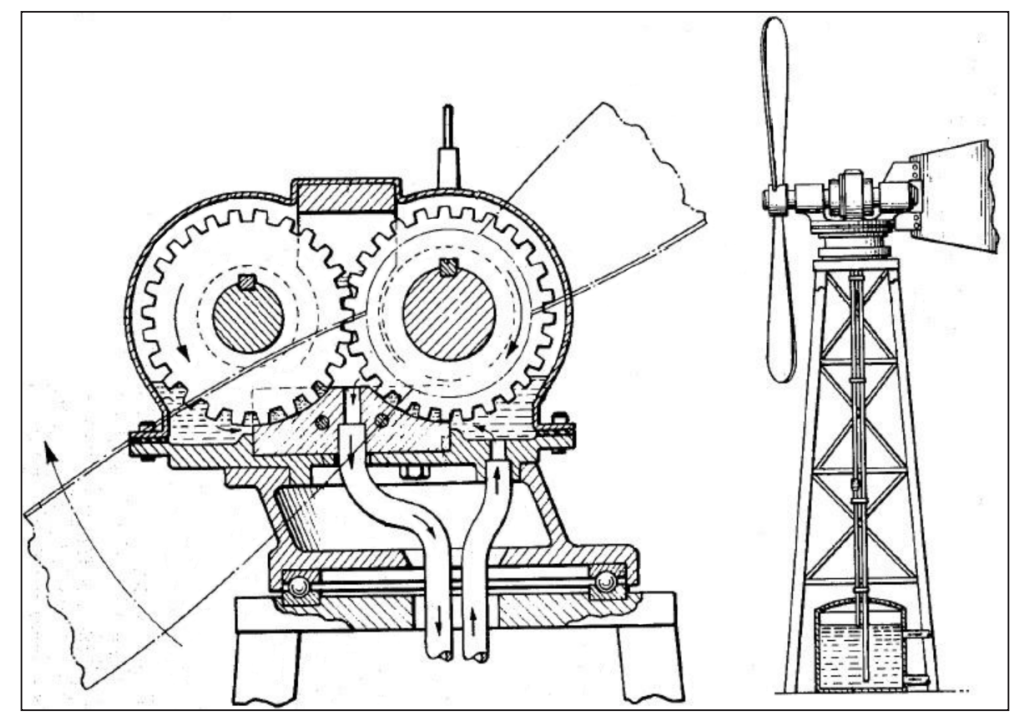

2 pav. Vejo mechaninès energijos transformavimo i šilumą įrenginys naudojant hidraulinę sistemą kaip šilumos generatorių [4] 
Vejjaračio ašis jungiama su antrosios grandies, elektrinès ar hidraulinès sistemos, ̣̇renginio ašimi tiesiogiai arba panaudojant reduktorius. Didesnès generuojamos galios vejo jègainèse dar naudojama sankaba ir pavarų děžè [7]. Antroji grandis elektrinèje sistemoje yra elektros generatorius, o hidraulineje - hidraulinis siurblys su hidrauline sistema $[4,10]$ arba skysčio maišytuvas-plaktuvas [13]. Elektrinès sistemos atveju šiluma gaunama tik tolimesnèse grandyse, jau naudojant pagamintą elektrą. Tačiau gaminant elektrą dalis mechaninès ir elektromagnetinès energijos prarandama pačiame elektros generatoriuje (pvz., trinčiai guoliuose nugalèti ir pan.), ši energijos dalis transformuojasi $\mathfrak{i}$ šilumą, kuri išsisklaido aplinkoje. Hidraulinèje sistemoje mechanine hidraulinio siurblio energija verčiama $\mathfrak{i}$ skysčio mechaninę energiją, vèliau skystis vamzdžiais gali būti transportuojamas ị reikiamą vietą ir praleidžiamas pro įvairias kliūtis: angas, diafragmas, droselius ir pan., tokiu būdu generuojama šiluma. Kaip ir elektrinèje sistemoje, dalis iš vejaračio gaunamos mechaninès energijos pačiame hidrauliniame siurblyje virsta ị šilumą, tačiau viena šios šilumos dalis išsisklaido ị aplinką, o kita atiduodama skysčiui - didejja skysčio temperatūra, taigi jau antroje grandyje generuojama šiluma. Tokios hidraulinès sistemos dar vadinamos „hidraulinio stabdžio" sistemomis, panašūs įrenginiai yra įdiegti ir veikia [14], tačiau nèra paplitę.

Patalpinus hidraulinị siurbli $\mathfrak{i}$ skystį, visa siurblyje išsiskirianti šiluma būtų atiduodama skysčiui arba šilumnešiui. Esant techninèms galimybėms, racionalu visą hidraulinę sistemą (siurblį su vamzdžiais, kliūtimis ir šilumokaičiu) patalpinti ị akumuliacinę talpą (1 pav.), o siurblio veleną sujungti su vejjaračio velenu. Toks sprendimas atitinką schemą "Vejjaratis - šilumos generatorius ir akumuliatorius - pastato šildymo sistema“. Hidraulinio siurblio korpusą padengus termoizoliacija, sumažinami šilumos nuostoliai ił aplinką, tada pagrindinè siurblyje išsiskiriančios šilumos dalis atitenka skysčiui - šilumnešiui. Siurbliui perkaisti neleidžia pats skystis: atidavęs šilumą akumuliacinèje talpoje arba šilumokaityje, í siurblị îsiurbiamas (grịžtantis) skystis turi sumažẻjusią temperatūrą. Kai hidrauliné sistema yra hidraulinis maišytuvas, jis talpinamas tiesiai $\mathfrak{i}$ akumuliacinę talpą (3 pav.).

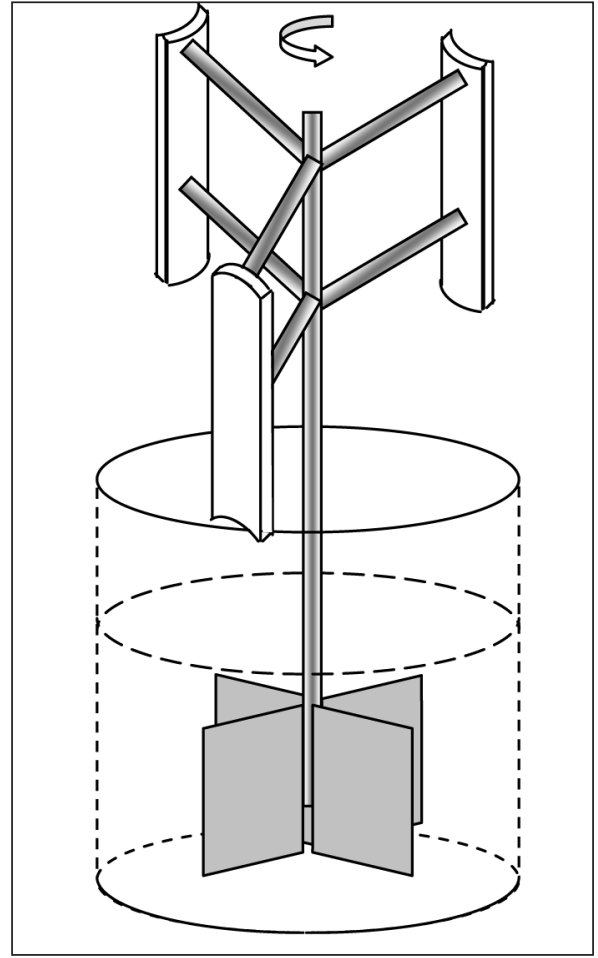

3 pav. Vejo mechaninès energijos transformavimo i šilumą irenginys naudojant skysčio maišytuvą

Dažniausiai maišytuvas - tai vertikali ašis, prie kurios tam tikra tvarka pritvirtintos iqvairiu formų mentys. Šiuo atveju turi būti suderinamumas tarp maišytuvo ir akumuliacinès talpos matmenų. Taip pat ant akumuliacinès talpos sienelių gali būti montuojamos kreipiančiosios skysčio turbulizacijai didinti. Maišytuvo ašis jungiama su vèjaračio ašimi per movą arba reduktorių. Maišytuvo mentys gali būti montuojamos ir tiesiai ant prailgintos vejjaračio ašies. Taip pat, kaip ir naudojant hidraulinị siurblį, beveik visa išsiskyrusi šiluma atiduodama skysčiui. Palyginti hidraulinę sistemą su elektrine, hidraulinès sistemos atveju antroje grandyje energijos nuostoliai gali būti mažesni. Tokios sistemos kiekybinis įvertinimas yra toliau aprašyto tyrimo objektas.

Lyginant šias sistemas pagal šilumos paskirstymą patalpose, elektriné sistema yra universalesné, nes tokiu atveju yra galimybė ir šildyti patalpas tiesiogiai elektros prietaisais, ir kaupti šiluminę energiją šildant akumuliacinès talpos vandenị. Reikia pažymèti, kad tiesioginio šildymo elektra galimybè nèra didelè dèl generuojamos energijos ir poreikio netolygumo bei dèl elektros prietaisų ir tiekiamos energijos techninių parametrų 
nesuderinamumo. Hidraulinei sistemai visada bus reikalinga akumuliacinè talpa, kuri sudaro sąlygas ị šildymo sistemą integruoti dar daugiau atsinaujinančiųjų ar alternatyviųjų energijos šaltinių - saulés kolektoriuose [15] gaminamą energiją, nuotekų šiluminę energiją ir pan.

Vèjo energija generuotą šilumą galima naudoti pastatams šildyti ir netiesiogiai. Gauta šiluma galima „ikrauti“ gruntą (4 pav.) ir akumuliuoti šilumą, išvedžiojus hidraulinès sistemos vamzdžius grunte po pastatu arba šalia pastato, kur įrengtas šilumos siurblio vanduo / gruntas (geoterminio šildymo sistemos) kolektorius [16]. Taip pat vèju generuota šiluma galima tirpinti ledą ir sniegą nuo pastato stogo ar nuo kito paviršiaus.

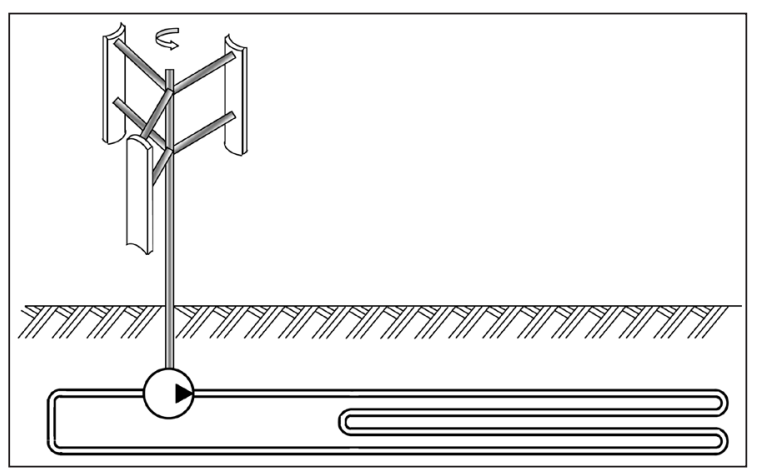

4 pav. Vejjo energijos naudojimas grunto šiluminei j̨krovai

Nors vejjo energijos transformavimo ị šilumą hidraulinès sistemos turi daugybę privalumų, vis dar manoma, kad tokiu būdu generuojamos energijos kiekiai per maži, o didesnès galios vejjo jègainèse tikslingiau gaminti elektrą, dalị jos vèliau pagal poreikius panaudoti šilumos gamybai. Todèl vejjo energijos transformavimo ị šilumą hidraulinès sistemos praktikoje naudojamos labai retai. Išsamiai situacijos analizei buvo vykdytas vèjo energijos panaudojimo šilumai gaminti taikant hidraulinę sistemą galimybių tyrimas, jo rezultatai pateikiami šiame straipsnyje.

\section{EKSPERIMENTINĖ IૃRANGA IR METODIKA}

Eksperimentinis įrenginys buvo skirtas vèjo jègainès su hidrauline sistema darbui modeliuoti (5 pav.). Vietoje besisukančio vejjaračio naudotas trifazis asinchroninis keturių polių $1,5 \mathrm{~kW}$

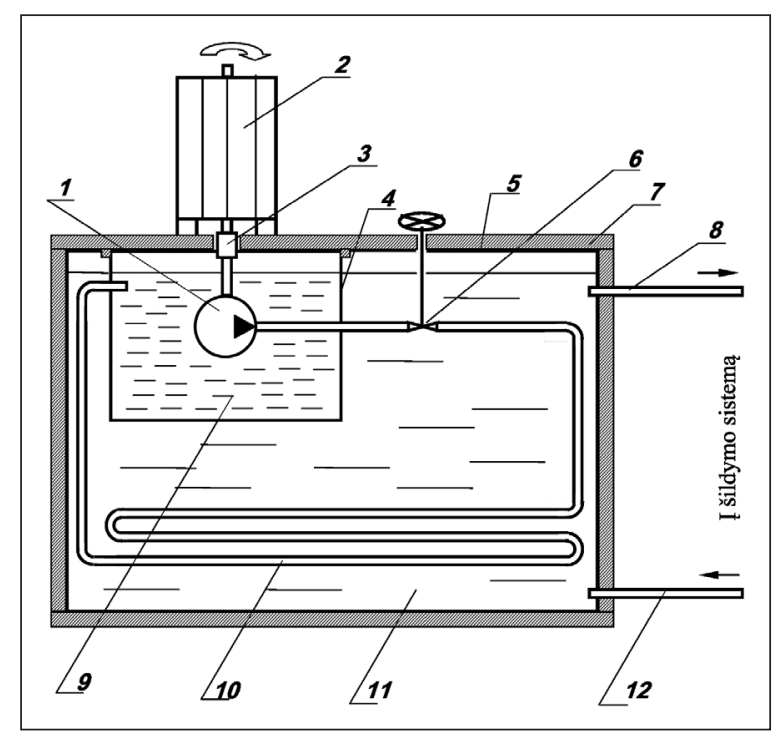

5 pav. Eksperimentinio stendo schema: 1 - krumpliaratinis siurblys; 2 - elektros variklis; 3 - mova; 4 - alyvos bakas; 5 - akumuliacinè talpa; 6 - reguliuojamasis ventilis (hidraulinè apkrova); 7 - termoizoliacija; 8 - i šildymo sistemą tiekiamo šilumnešio atvamzdis; 9 - alyva; 10 - šilumokaitis; 11 - šilumnešis (vanduo); 12 - iš šildymo sistemos grižtančio šilumnešio atvamzdis

galios elektros variklis (BEVI-4AK2 90L-4B14, $\left.\cos \varphi=0,77, \eta_{\text {el. } .}=0,828\right)$. Eksperimentiniu tyrimų metu multimetru ESCORT 3136A (tikslumo klase 0,02 ) buvo matuojama kiekvienos prie elektros tinklo prijungtos fazès ịtampa $U$ ir srovès stiprumas $I$. Multimetro parodymai periodiškai buvo nuskaitomi ir ịrašomi ị kompiuterio duomenų archyvą, apskaičiuojama elektros variklio sunaudojama galia $P_{\text {el_var }}$. Pats elektros variklis buvo pritvirtintas prie alyvos rezervuaro dangčio, o jo velenas per movą buvo sujungtas su hidraulinio krumpliaratinio siurblio (Vivolo-X2P5702, $26,2 \mathrm{~cm}^{3} /$ aps.) velenu. Hidraulinëje sistemoje naudojama 201 mineralinès alyvos HV32. Hidraulinis siurblys panardintas ị alyvą, esančią stačiakampio formos plieniniame alyvos rezervuare (BEK 20/E/E, 0,40 ×0,298 $\times 0,27 \mathrm{~m}^{3}$, sienelès storis $\delta=4 \mathrm{~mm}$ ). Siurblio spaudiminè linija (skersmuo $d_{v}=20 \mathrm{~mm}$ ) sujungta su šilumokaičiu. Pratekèjusi pro šilumokaitį alyva grižtamuoju vamzdžiu tekèdavo atgal ị alyvos rezervuarą. Skysčiui droseliuoti naudotas reguliuojamasis ventilis (ventilio padètis pilnais apsisukimais nuo uždarytos padèties $\gamma=1 ; 0 ; 1,5 ; 2,0 ; 2,5 ; 3,0$ ir 9,0 - pilnai atidarytas). Sistemos apkrova buvo keičiama mažinant ar didinant reguliavimo ventilio pralaidumą. 
Alyvos rezervuaras kartu su šilumokaičiu buvo ịstatytas $\mathfrak{i}$ akumuliacinę talpą - stačiakampio formos plienini rezervuarą (BEK 150/E/E, $\left.0,75 \times 0,488 \times 0,565 \mathrm{~m}^{3}, \delta=4 \mathrm{~mm}\right)$, it kuri galima prileisti 1401 vandens. Akumuliacinès talpos dangtyje (sienelès storis $\delta_{d}=6 \mathrm{~mm}$ ) padaryta stačiakampé anga $\left(0,42 \times 0,32 \mathrm{~m}^{2}\right)$ alyvos rezervuarui. Abu dangčiai buvo vienoje horizontalioje plokštumoje, tačiau tarpusavyje nesiliete $-1 \mathrm{~cm}$ pločio ir $6 \mathrm{~mm}$ gylio tarpas buvo termiškai izoliuotas ir užsandarintas.

Priklausomai nuo akumuliacinès talpos užpildymo eksperimentiniu stendu galima imituoti tris vejo jègainès su hidrauline sistema modelius. Pirmuoju atveju akumuliacinė talpa neužpildoma vandeniu (jei buvo užpildyta, tai visiškai nudrenuojama ir išdžiovinama): vandens padavimo $\mathfrak{i}$ ir nuvedimo iš akumuliacinès talpos ventiliai yra uždaryti, dangtis užsandarinamas. Tokiu būdu talpoje lieka ir gali būti šildomas tik oras. Pati hidrauliné sistema: alyvos bakas, vamzdžiai, ventilis ir šilumokaitis - termiškai izoliuojama, iš išorès apvyniojant akmens vata, - nèra šilumos nuvedimo, tik minimalūs šilumos nuostoliai $\mathfrak{i}$ aplinką. Pirmasis modelis buvo ištirtas pirmiausiai, tyrimų rezultatai pristatomi šiame straipsnyje. Antruoju atveju naudojama akumuliacinè talpa - ji užpildyta vandeniu, o nuo hidraulinès sistemos termoizoliacija nuimta. Trečiuoju atveju vietoje vandens akumuliacine talpa užpildoma vienu iš grunto pavyzdžių - tiriamoji sistema skirta gruntui „ikrauti“.

Vejjaračio sūkiai imituoti keičiant elektros variklio veleno sukimosi dažnị ( $n=0,5-5,0$ aps./s) elektriniu dažnio keitikliu (Mitsubishi Electric - FRD740-036SC-EC, trif., $1,5 \mathrm{~kW}, 0,2 \ldots 400 \mathrm{~Hz}$ ). Eksperimentinių tyrimų metu dažnio keitiklio indikatoriuje buvo nuskaitoma elektros varikliui užduotas dažnis $n_{\text {užd }}$ taip pat itampa ir sroves stiprumas. Nuskaityti parodymai periodiškai buvo irašomi į duomenų archyvą kompiuteryje.

Veleno sukimosi dažnis buvo matuojamas tachometru (Testo 465; paklaida: 0,01 aps./min).

Eksperimentinių tyrimų metu alyvos temperatūra matuota 4-iuose taškuose: alyvos rezervuare, prieš reguliuojamajji ventili, prieš šilumokaitị ir už šilumokaičio. Akumuliacinę talpą užpildžiusios medžiagos (vandens ar grunto pavyzdžio) temperatūrą galima matuoti taip pat 4-iuose taškuose. Kadangi straipsnyje pateikiamų eksperimentinių tyrimų metu akumuliacinè talpa buvo tuščia, akumuliacinejje talpoje sumontuotų termojutiklių parodymai nepateikiami ir neanalizuojami. Temperatūrai matuoti naudoti termovaržiniai jutikliai (TJ4-Pt100, tikslumo klasė 1/3B). Termojutiklių parodymai nuskaitomi ir perduodami i kompiuterị duomenų kaupikliais „PT-104 Data Logger“, tikslumas esant $25{ }^{\circ} \mathrm{C}-0,01{ }^{\circ} \mathrm{C}$. Kiekvienas kaupiklis turi keturis iejjimo kanalus, skirtus prijungti Pt100 arba Pt1000. Naudoti du kaupikliai 8-ių jutiklių parodymams nuskaityti. Iš kaupiklių duomenys per USB jungtis perduodami ị kompiuteri. Naudota kaupiklių gamintojų siūloma programine iranga: „PicoLog Recorder“ ir "PicoLog Player“. Kiekvieno eksperimento metu alyvos temperatūros buvo matuojamos ir registruojamos ne mažiau nei $20 \mathrm{~min}$. Tada nustatytas alyvos temperatūros kitimo greitis ir apskaičiuota generuojama šiluma.

Slègis matuotas prieš reguliuojamajji ventilị: mechaniniu manometru (WIKA, 0-25 bar, tikslumo klase 1,6) ir slègio jutikliu (NAH 25.0 A, 0-25 bar, 4-20 mA, matavimo tikslumas 0,3\%); už reguliuojamojo vožtuvo - slègio jutikliu (NAH 2.5 A, 0-2,5 bar, 4-20 mA, 0,3 \%). Slègio jutiklių parodymų vizualizacijai instaliuoti du indikatoriai (LUMEL N20-6112008, 5 skaitmenų), per šiuos indikatorius jutikliai gavo $24 \mathrm{~V}$ nuolatinę maitinimo įtampą. Indikatorių parodymai periodiškai buvo ịrašomi į duomenų archyvą kompiuteryje. Eksperimentinių tyrimų metu hidraulinès sistemos apkrova apskaičiuota kaip skirtumas tarp slègio jutiklių prieš ir už reguliuojamojo ventilio parodymų $\left(\Delta p=p_{1}-p_{2}\right)$.

Eksperimentinių tyrimų rezultatų atkuriamumui ir patikimumui patikrinti kiekvienai bandymų serijai, atliktai tomis pačiomis sąlygomis, buvo apskaičiuojami statistiniai parametrai ir patikrinta, ar Kochreno kriterijaus, variacijos koeficiento ir bendrosios rezultato santykinès paklaidos reikšmès neviršija leistinų reikšmių $[17,18]$. Nustatyta, kad eksperimentinių tyrimų rezultatai pakankamai tikslūs, patikimi ir atkuriami.

Eksperimentiniame stende hidraulinio siurblio velenas sukamas elektros varikliu, o siurblio išvystoma galia gali būti nustatoma pagal elektros variklio galią:

$$
P_{s}=\eta_{\text {el. } .} P_{\text {ell. }},
$$

čia: $\eta_{e l . v .}$ - elektros variklio naudingumo koeficien-

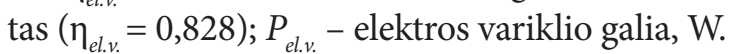


Elektros variklio galia, išmatavus kiekvienos fazès įtampas ir sroves, apskaičiuojama pagal formulę:

$$
P_{\text {el. } .}=U_{A} I_{A}, \cos \varphi+U_{B} I_{B} \cos \varphi+U_{C} I_{C} \cos \varphi,
$$

čia: $U_{A}, U_{B}, U_{C}$ - itampa tarp atitinkamos elektros variklio fazès ir „nulio“, V; $I_{A}, I_{B}, I_{C}$ - atitinkamos elektros variklio fazès sroves stiprumas, $\cos \varphi-\mathrm{fa}$ zių skirtumas tarp įtampos ir srovès $(\cos \varphi=0,77)$.

Siurblio galia gali būti apskaičiuojama ir pagal siurblio veleno judesị:

$$
P_{s}=\omega M=2 \pi n M
$$

čia: $M$ - siurblio veleno sukimo momentas, $N \cdot m$; $\omega$ - siurblio veleno sukimosi kampinis greitis, $\mathrm{rad} / \mathrm{s}: \omega=2 \pi n$, kur: $n$ - siurblio veleno sukimosi dažnis, aps./s.

Veikiant hidrauliniam siurbliui, dalis siurblio energijos transformuojama $\mathfrak{i}$ skysčio (alyvos) mechaninę energiją, dalis energijos pačiame hidrauliniame siurblyje transformuojasi ił šilumą ir perduodama alyvai. Hidraulinè sistema: hidraulinis siurblys; vamzdžiai, kuriais teka alyva; reguliuojamasis ventilis; šilumokaitis ir alyvos bakas, patalpinti akumuliacinejje talpoje, kuri gali būti neužpildyta, užpildyta vandeniu arba grunto pavyzdžiu. Taigi alyvos kaupiama šiluma per hidraulinę sistemą: alyvos rezervuaro, vamzdžių ir šilumokaičio sieneles, reguliuojamojo ventilio korpusą, perduodama (arba beveik neperduodama, jei hidraulinè sistema termiškai izoliuota) medžiagai akumuliacinëje talpoje. Taip pat reikia ivvertinti ir šilumos nuostolius ị aplinką.

Šilumos balanso lygtis:

$$
P_{s}-Q_{a k}-Q_{n}=Q_{s}+P_{a l}-Q_{a k}-Q_{n}=0,
$$

čia: $Q_{s}$ - energijos dalis per laiko vienetą, kuri hidrauliniame siurblyje transformuojasi ị šilumą ir perduodama skysčiui, $\mathrm{W} ; P_{a l}$ - alyvai suteikiama mechaninès energijos dalis, W; $Q_{a k}$ - medžiagai akumuliacineje talpoje per laiko vienetą perduodama šiluma, $\mathrm{W} ; Q_{n}-$ šilumos nuostoliai ị aplinką per laiko vienetą, $\mathrm{W}$.

Iš siurblio alyva teka vamzdžiu, prateka pro reguliuojamajji ventili, teka vamzdiniu-spiraliniu šilumokaičiu ir vamzdžiu grąžinama ị alyvos rezervuarą. Kadangi skystis, nugaledamas hidrauli- nị pasipriešinimą, teka uždaru ratu, visa jo mechaninė energija virsta ị šilumą:

$$
P_{a l}=Q_{r v}+Q_{v m z .}+Q_{\xi}
$$

čia: $Q_{r v}$ - reguliuojamame ventilyje dèl alyvos mechaninès energijos nuostolių kliūtyje per laiko vienetą generuojama šiluma, $\mathrm{W} ; Q_{v m z .}-$ vamzdžiuose (vamzdžiuose iki šilumokaičio ir iš šilumokaičio ị alyvos rezervuarą) dèl trinties tekant alyvai i šilumą per laiko vienetą virstanti energija, $\mathrm{W} ; Q_{\breve{s}}$ - šilumokaityje dèl trinties tekant alyvai $\mathfrak{i}$ šilumą per laiko vienetą virstanti energija, W.

Šilumos nuostoliai:

$$
Q_{n}=Q_{n \_a l}+Q_{n \_a k},
$$

čia: $Q_{n \_a l}-$ šilumos nuostoliai ị aplinką per alyvos bako dangtị ir hidraulinio siurblio veleną, per laiko vienetą, $\mathrm{W} ; Q_{n a k}-$ šilumos nuostoliai ị aplinką per akumuliacinés talpos sieneles, W.

Siurblio energija yra transformuojama ị šilumą:

$$
P_{s}=Q_{s}+Q_{r v}+Q_{v m z .}+Q_{\check{s}}-Q_{a k}-Q_{n \_a l}-Q_{n \_a k} .
$$

Keičiant reguliuojamojo ventilio rankenèlès padètí, alyvos tèkmè yra droseliuojama - keičiamas ventilio vietinių nuostolių koeficientas $\zeta$, kinta ne tik kliūtyje generuojamos šilumos kiekis, bet tuo pačiu ir pasipriešinimas alyvos tèkmei - kinta apkrova siurbliui. Apkrovą siurbliui patogu išreikšti per slègio nuostolius $(\Delta p)$ kliūtyje:

$$
\begin{aligned}
& \Delta p=\rho_{a l} g \zeta \frac{\mathrm{v}^{2}}{2 g}=8 \rho_{a l} \zeta \frac{G^{2}}{\pi^{2} d^{4}}= \\
& 8 \rho_{a l} \zeta \frac{\left(\eta_{t} n V_{s_{-a p s .}}\right)^{2}}{\pi^{2} d^{4}}=8 \rho_{a l} \frac{\eta_{t}^{2} V_{s_{-} a p s .}^{2}}{\pi^{2} d^{4}} \zeta n^{2},
\end{aligned}
$$

čia: $\rho_{a l}$ - alyvos tankis, $\mathrm{kg} / \mathrm{m}^{3} ; g$ - laisvojo kritimo pagreitis, $\mathrm{m} / \mathrm{s}^{2} ; \zeta$ - reguliuojamojo ventilio vietiniu nuostolių koeficientas; $G$ - alyvos debitas, $\mathrm{m}^{3} / \mathrm{s} ; d$-vamzdžio išèjime skersmuo (visiems vamzdžiams vienodas), $\mathrm{m} ; v$ - vidutinis alyvos tèkmès greitis, $\mathrm{m} / \mathrm{s} ; \eta_{t}$ - tūrinis siurblio naudingumo koeficientas; $V_{\text {saaps. }}$ - vieno apsisukimo metu iš siurblio išstumiamos alyvos kiekio tūris $\left(V_{\text {s_aps. }}=26,2 \mathrm{~cm}^{3} /\right.$ aps. $), \mathrm{m}^{3} /$ aps.

Alyvai pratekant pro kliūtị - reguliuojamąji ventili, skysčio mechaninès energijos dalis 
(vietiniai hidrauliniai nuostoliai), virtusi ị šilumą, apskaičiuojama taip:

$$
Q_{r v}=\rho_{a l} g G \zeta \frac{v^{2}}{2 g}=8 \rho_{a l} \zeta \frac{G^{3}}{\pi^{2} d^{4}} .
$$

Alyvai tekant vamzdžiais ir šilumokaičiu, dalis skysčio mechaninès energijos dèl trinties (kelio hidrauliniai nuostoliai) transformuojasi ị šilumą:

$$
Q_{v m z .}+Q_{\check{s}}=\rho_{a l} g G \lambda \frac{1}{d} \frac{v^{2}}{2 g}=8 \rho_{a l} \lambda \frac{1}{d} \frac{G^{3}}{\pi^{2} d^{4}},
$$

čia:

$$
\begin{aligned}
& \lambda=\lambda_{v m z_{\_} i t}+\lambda_{\check{s}}+\lambda_{v m z_{-} i s^{s}} \\
& l=l_{v m z_{\_} i t}+l_{\breve{s}}+l_{v m z_{-} i s},
\end{aligned}
$$

čia: $\lambda$ - hidraulinès trinties koeficientas skaičiuojamas kaip koeficientu - vamzdžiui iki šilumokaičio $\left(\lambda_{v m z-i t}\right)$, šilumokaityje $\left(\lambda_{s}\right)$ ir vamzdžiui nuo šilumokaičio iki alyvos rezervuaro $\left(\lambda_{v m z}\right.$ is $)$ - suma; $l$ - vamzdžių - iki šilumokaičio $\left(l_{v m z \_i t}\right)$, šilumokaičio $\left(l_{s}\right)$ ir nuo šilumokaičio iki alyvos rezervuaro $\left(l_{v m z_{i} i s}\right)$ - suma, $\mathrm{m}$.

Âlyvai hidraulinèje sistemoje suteikiama šiluma:

$$
\begin{aligned}
& Q_{a l}=Q_{s}+Q_{r v}+Q_{v m z .}+Q_{\check{s}}-Q_{n}= \\
& m_{a l} c_{p_{-} a l} \frac{\Delta T_{a l}}{t}-Q_{n},
\end{aligned}
$$

čia: $m_{a l}=\rho_{a l} V_{\mathrm{al}} ; m_{a l}$ - alyvos masé, $\mathrm{kg} ; \rho_{a l}-$ alyvos tankis, $\mathrm{kg} / \mathrm{m}^{3} ; V_{a l}$ - alyvos tūris hidraulinèje sistemoje, $\mathrm{m}^{3} ; c_{p_{-} a l}$ - alyvos savitoji šiluma, $\mathrm{J} /(\mathrm{kg} \cdot \mathrm{K})$; $\Delta T_{a l}\left(\Delta T_{a l}=T_{a l}-T_{0}\right)$ - alyvos temperatūros pokytis, $\mathrm{K} ; T_{a l}$ - alyvos temperatūra realiuoju laiku, $\mathrm{K}$ (matuota termovaržomis); $T_{0}$ - alyvos temperatūra pradiniu laiko momentu, $\mathrm{K}$ (eksperimento pradžioje: $T_{0}=T_{a p l}=19-20{ }^{\circ} \mathrm{C}$; $t$ - laiko intervalas, per kurị išmatuotas $\Delta T_{a p} \mathrm{~s}$.

Kaip jau buvo minèta anksčiau, pirmiausia ištirtas pirmasis vejo jejgainès su hidrauline sistema modelis, tai yra eksperimentinių tyrimų metu akumuliacinè talpa buvo tuščia. Visa hidraulinejje sistemoje generuojama šiluma:

$$
Q=Q_{a l}=m_{a l} c_{p \_a l} \frac{\Delta T_{a l}}{t}-Q_{n},
$$

čia: $Q$ - hidraulineje sistemoje per laiko vienetą generuojama šiluma, W.
Hidraulinès sistemos efektyvumas gali būti apskaičiuojamas pasinaudojus (1), (2) ir (14) lygtimis:

$$
\eta=\frac{Q}{P_{s}}
$$

Kitų eksperimentinių tyrimų metu, imituojant kitus vejo jeggainès su hidrauline sistema modelius, šilumos perdavimas medžiagai (vandeniui arba gruntui), esančiai akumuliacineje talpoje, vyksta per alyvos bako sieneles, šilumokaityje per vamzdžio sieneles, taip pat per kitus hidraulinès sistemos vamzdžius ir reguliuojamojo ventilio korpuso išorini paviršių.

\section{REZULTATAI}

Eksperimentinių tyrimų metu hidraulinio siurblio velenas imituojant vèjo jègainès darbą buvo sukamas dažniu $n=0,5 ; 1,0 ; 1,5 ; 2,0 ; 2,5 ; 3,0 ; 3,5$; $4,0,4,5$ ir 5 aps./s. Tai mažų dažnių sritis, imituojamas tiesioginis vejaračio veleno jungimas su siurblio velenu nenaudojant reduktoriaus. Eksperimentinių tyrimų metu apkrova buvo keičiama reguliuojamojo ventilio atidarymu $(\gamma$, apsisukimais arba rad), pradedant nuo visiškai uždaryto $(0$ aps.) iki visiškai atidaryto ( 9 aps.) ventilio. Bandymai vykdyti prie $\gamma=1,0 ; 1,5 ; 2,0 ; 2,5 ; 3,0$; 9,0 aps. Intervale nuo $\gamma=3,0$ aps. iki $\gamma=9,0$ aps. hidraulinès sistemos pasipriešinimas tèkmei kito labai nežymiai, todèl vykdant bandymus apsiribota minètomis dvejomis $\gamma$ reikšmèmis. Eksperimentiškai ištirtas pirmasis eksperimentinio stendo modelis, kai alyvos bakas, vamzdžiai ir šilumokaitis termiškai izoliuoti, o akumuliacinè talpa tuščia - neužpildyta nei vandeniu, nei gruntu. Kiekvieno bandymo pradžioje alyvos temperatūra buvo aplinkos temperatūros $T_{a l}=19-20^{\circ} \mathrm{C}$.

Maksimali modeliuojamos vejjo jègainès apkrova būtų pasiekiama visiškai uždarius reguliuojamąji ventili $(\zeta \rightarrow \infty)$. Siurblio velenas būtų sukamas maksimaliu sukimo momentu $M_{s}=M_{s_{\text {max }}}$, sukimosi dažnis smarkiai sumažètų. Alyvos slègis spaudiminèje linijoje prieš kliūti pasiektų maksimalią reikšmę $p=p_{\max }$ o jos debitas sistemoje $G \approx 0 \mathrm{~m}^{3} / \mathrm{s}$. Visa šiluma būtų generuojama siurblyje - alyva țtraukiama $\mathfrak{i}$ ji ir slegiama bei maišoma jame, vèliau ji išspaudžiama atgal $\mathfrak{i}$ alyvos baką, o šilumokaitis būtų atjungtas (alyva per ji necirkuliuotų dèl uždaryto ventilio). 
Eksperimentiškai ịvykdyti bandymus prie visiškai uždaryto ventilio ( $\gamma=0$ aps.) nepavyko, nes dèl išaugusio sukimo momento elektros variklio apkrova pasieke maksimalias leistinas varikliui elektros srovès reikšmes ( $\mathrm{I} \geq 5 \mathrm{~A}$ ) ir suveikè apsauga. Maksimali hidraulinès sistemos apkrova atitiko $\gamma=1,0$ aps. reguliuojamojo ventilio padèti. Prie šios ventilio padèties pavyko padaryti dviejų bandymų seriją, kol pasiektos maksimalias elektros variklio elektros srovès reikšmes. Tai buvo bandymai, hidraulinio siurblio veleno sukimosi dažniui esant $n=0,5$ ir 1,0 aps./s (6 pav.). Siurblio gaunama iš elektros variklio galia: $P_{s}=202 \mathrm{~W}$, kai $n=0,53$ aps. $/ \mathrm{s}$ ir $P_{s}=405 \mathrm{~W}$, kai $n=0,92$ aps./s (7 pav.). Šiuo atveju apkrova atitiko sleggi $p=10,1$ bar $(n=0,53$ aps./s) ir $p=16,2$ bar $(n=0,92$ aps./s). Hidraulineje sistemoje sugeneruota šiluma: $Q=90 \mathrm{~W}(n=0,5$ aps./s) ir $Q=187 \mathrm{~W}(n=1,0 \mathrm{aps} . / \mathrm{s})(8 \mathrm{pav}$.$) .$
Kita bandymų serija vykdyta reguliuojančiojo ventilio padéčiai esant $\gamma=1,5$ aps. Hidraulinio siurblio veleno sukimosi dažnis buvo keičiamas nuo $n=0,5$ aps./s iki $n=5,0$ aps./s. Hidraulinio siurblio gaunama galia kito nuo $P_{s}=175$ iki $856 \mathrm{~W}$. $\gamma=1,5$ aps. apkrova atitiko slegi $p=3,4$ bar, kai $n=0,62$ aps./s ir slègis didejant siurblio veleno sukimosi dažniui didèjo iki $p=14,1$ bar, kai $n=4,7$ aps./s. Hidraulineje sistemoje sugeneruota šiluma kito nuo $Q=21 \mathrm{~W}$, kai $n=0,62 \mathrm{aps} . / \mathrm{s}$, iki $Q=578 \mathrm{~W}$, kai $n=4,7$ aps./s.

Kai reguliuojančiojo ventilio padetis buvo $\gamma=2,0$ aps., siurblio gaunama galia kito nuo $P_{s}=170$ iki $351 \mathrm{~W}$. Apkrova $\gamma=2,0$ aps., atitiko slègit $p=0,82$ bar, kai $n=0,48$ aps./s ir $p=7,1$ bar, kai $n=4,95$ aps./s. Hidraulineje sistemoje sugeneruota šiluma kito nuo $Q=17 \mathrm{~W}$, kai $n=0,48$ aps./s, iki $Q=294 \mathrm{~W}$, kai $n=4,95$ aps./s.
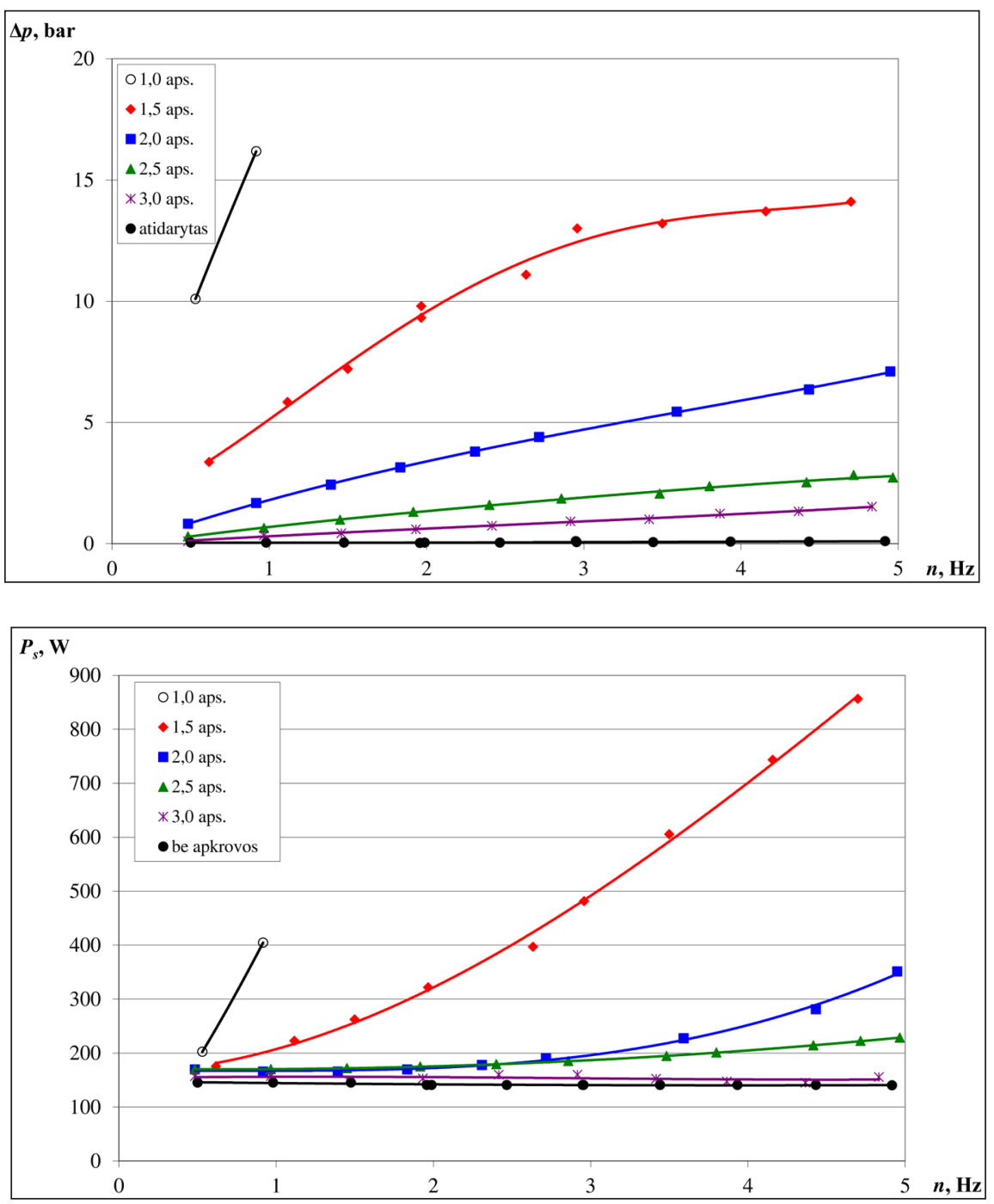

6 pav. Hidraulinės sistemos apkrovos priklausomybė nuo veleno sukimosi dažnio, kai reguliuojamojo ventilio padètis $\gamma=1,0 ; 1,5 ; 2,0 ; 2,5 ; 3,0$ aps. ir be apkrovos

7 pav. Siurblio gaunamos galios priklausomybè nuo veleno sukimosi dažnio, kai apkrova $\gamma=1,0 ; 1,5 ; 2,0 ; 2,5 ; 3,0$ aps. ir be apkrovos 


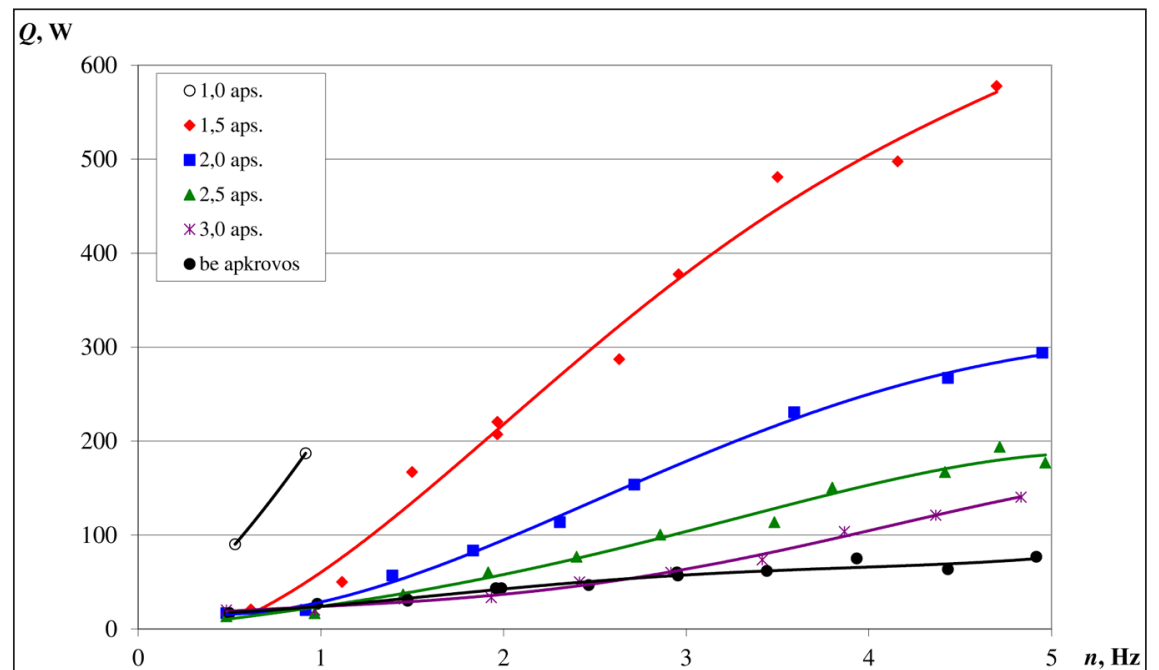

8 pav. Hidraulineje sistemoje generuojamos šilumos kiekio priklausomybè nuo veleno sukimosi dažnio, kai apkrova $\gamma=1,0 ; 1,5$; 2,$0 ; 2,5 ; 3,0$ aps. ir be apkrovos

Esant $\gamma=2,5$ aps., $P_{s}$ kito nuo 170 iki $229 \mathrm{~W}$; $p=0,3$ bar, kai $n=0,49$ aps./s ir $p=2,7$ bar, kai $n=4,97$ aps./s, o sugeneruota šiluma kito nuo $Q=15 \mathrm{~W}$, kai $n=0,49$ aps./s, iki $Q=194 \mathrm{~W}$, kai $n=4,72$ aps./s. Kai $\gamma=3,0$ aps., $P_{s}$ kito nuo $147 \mathrm{iki}$ $157 \mathrm{~W} ; p=0,1$ bar, kai $n=0,48$ aps./s ir $p=1,5$ bar, kai $n=4,83$ aps./s, o $Q=18 \mathrm{~W}$, kai $n=0,48$ aps./s, ir $Q=140 \mathrm{~W}$, kai $n=4,83$ aps./s.

Kita bandymų serija, kai hidrauline sistema dirba be apkrovos, - reguliuojantysis ventilis visiškai atidarytas ( $\gamma=9,0$ aps.). Kaip ir ankstesnių serijų metu, hidraulinio siurblio veleno sukimosi dažnis buvo keičiamas nuo $n=0,5$ aps./s iki $n=5,0$ aps./s žingsniu - 0,5 aps./s. Siurblio gaunama galia $P_{s}$ kito nuo 140 iki 146 W. Hidraulinès sistemos be apkrovos pasipriešinimas skysčio tèkmei sudarè slègi $p \approx 0$ bar, kai $n=0,5$ aps./s ir kito iki $p=0,1$ bar, kai $n=4,92$ aps./s. Be apkrovos dirbančioje sistemoje generuojama šiluma kito nuo $Q=17 \mathrm{~W}$, kai $n=0,50 \mathrm{aps} . / \mathrm{s}$, iki $Q=77 \mathrm{~W}$, kai $n=4,92 \mathrm{aps} . / \mathrm{s}$.

Lyginant hidrauline sistema generuojamos šilumos kiekius prie skirtingų siurblio veleno sukimo dažnių, nustatyta, kad prie $n \approx 0,5$ aps./s, didinant apkrovą nuo $\gamma=9,0$ aps. iki $\gamma=1,5$ aps., generuojamos šilumos kiekis kito labai nežymiai $Q=19 \pm 2$ W. Tik esant maksimaliai apkrovai $\gamma=1,0$ aps. generuojamos šilumos kiekis išaugo iki $Q=90 \mathrm{~W}$ - padidejo daugiau nei keturis kartus. Atitinkamai ir hidraulinès sistemos efektyvumas $Q / P_{s}$ išaugo nuo 0,1 iki 0,4 . Kai $n=1,0$ aps./s, generuojamos šilumos kiekis kito nuo $Q_{\min }=27 \mathrm{~W}$ (be apkrovos) iki $Q_{\max }=187 \mathrm{~W}$ $(\gamma=1,0$ aps. $)$ - padidejo taip pat daugiau nei keturis kartus. Sistemos efektyvumas didinant ap- krovą pakito nuo 0,2 iki 0,4. Kai $n=1,5$ aps./s, $Q$ kinta nuo $Q_{\min }=31 \mathrm{~W}$ iki $Q_{\max }=167 \mathrm{~W}$, tačiau jau prie mažesnès galimos apkrovos, kuri atitinka $\gamma=1,5$ aps., šiuo atveju generuojamos šilumos kieki galima padidinti $Q_{\max } / Q_{\min }=5,4$ karto, sistemos efektyvumas $(Q / P)$ prie $\gamma=1,5$ aps. pasiekia 0,6 ir išlieka didesnis nei 0,6 iki $n=5$ aps./s. Kai $n=2,0$ aps./s, $Q$ kinta nuo $Q_{\min }=43 \mathrm{~W}$ iki $Q_{\max }=220 \mathrm{~W}$, sistemos efektyvumas didesnis už 0,5 jau ir esant $\gamma=2,0$ aps. (nuo $n=2,5$ aps. $Q / P_{s} \geq 0,6$, kai $\gamma=2,0$ aps.). Kai $n=2,5$ aps./s, $Q$ kinta nuo $Q_{\min }=47 \mathrm{~W}$ iki $Q_{\max }=287 \mathrm{~W}$; kai $n=3,0 \mathrm{aps} . / \mathrm{s}$, $Q$ kinta nuo $Q_{\min }=57 \mathrm{~W}$ iki $Q_{\max }=377 \mathrm{~W}$; o Q/ $P_{s} \geq 0,5$ jau ir kai $\gamma=2,5$ aps. Kai $n=4,0$ aps./s, $Q$ kinta nuo $Q_{\min }=75 \mathrm{~W}$ iki $Q_{\max }=498 \mathrm{~W}$; o $Q /$ $P_{s} \geq 0,5$ jau ir kai $\gamma=3,0$ aps.; kai $n=5,0$ aps./s, $Q$ kinta nuo $Q_{\min }=77 \mathrm{~W}$ iki $Q_{\max }=577 \mathrm{~W}$. Maksimalus sistemos efektyvumas $Q / P_{s}=0,95$ pasiektas, kai apkrova $\gamma=2,0$ aps. ir $n=3,5$ aps./s Aukštas sistemos efektyvumas $Q / P_{s} \geq 0,80$, nustatytas esant apkrovai $\gamma=1,5$ aps. ir $n=3,0$ aps./s; kai apkrova $\gamma=2,0$ aps. ir $n=3,5$ aps./s; kai apkrova $\gamma=2,5$ aps. ir $n=4,5$ aps./s; kai apkrova $\gamma=3,0$ aps. ir $n=5,0$ aps./s, be apkrovos eksperimentiniame stende tirta hidraulinè sistema pasiekè maksimalu efektyvumą $Q / P_{s} \approx 0,5$, kai $n=4,0-5,0$ aps./s.

\section{IŠVADOS}

1. Eksperimentiškai ištirtos hidraulinès sistemos, varomos vejjo energijos, galimybès generuoti šilumą, kurią tikimasi panaudoti pastatams šildyti. Keičiant elektros variklio sukimosi dažnị nuo 0,5 iki $5 \mathrm{~Hz}$, imituotas vejjaračio darbas. Naudojama 
galia kito nuo 140 iki 856 W. Krumpliaratinio siurblio apkrova, sudaroma reguliuojamojo ventilio, tyrimų metu buvo keičiama nuo 0,04 (be apkrovos) iki 16,2 bar. Hidrauline sistema generuojamas šilumos kiekis kito nuo 15 iki $578 \mathrm{~W}$.

2. Eksperimentiškai nustatyta, kad siurblio veleno sukimosi dažniams esant $n=0,5-5,0 \mathrm{~Hz}$, generuojamos šilumos kiekis didinant apkrovą pastebimai išaugo tik artejant prie reguliuojamuoju ventiliu sudaromos apkrovos $\gamma \rightarrow 1,0-2,0$ aps. Maksimalus sistemos efektyvumas $(\eta=0,95)$ pasiektas esant siurblio veleno sukimo dažniui $n=3,5 \mathrm{~Hz}$ ir apkrovai $\gamma=2,0$ aps.

3. Nustatyta, kad hidraulinè šilumos generavimo sistema net ir neapkrauta pasiekia naudingumo koeficientą iki 0,5, o su apkrova efektyvumas išauga iki $>0,85$. Galima teigti, kad vejju varomos hidraulinès sistemos generuojamą šilumą galima naudoti ir kaip alternatyvų energijos šaltinį pastatams šildyti.

Gauta 20141217 Priimta 20150508

\section{Literatūra}

1. Andrejevas A., Morkūnas E. Technikos paminklai Lietuvoje. Vèjo malūnai. Vilnius: Mokslas, 1982. $164 \mathrm{p}$.

2. Ashiklan B. Wind motor operated heating system. United States Patent No. 3752395, 1973. P. 1-5.

3. Ashikian B. Wind operated heating system. United States Patent No. 3783858, 1974. P. 1-6.

4. Knecht J. E. Wind driven heating system. United States Patent No. 4366779, 1983. P. 1-8.

5. Europos parlamento ir Tarybos direktyva 2010/31/ES, 2010 m. gegužès 19 d. dèl pastatu energinio naudingumo L153. P. 13-35.

6. Černeckienè J., Ždankus T. Usage of the wind energy for heating of the energy-efficient build- ings: analysis of possibilities. Proceedings of 4th International Conference on Advanced Construction 2014. P. 236-237.

7. Petrauskas G., Adomavičius V. Vejjo energijos naudojimas elektrai gaminti. Kaunas, 2012. 167 p.

8. Li Q., Chen Q., Zhang X. Performance analysis of a rooftop wind solar hybrid heat pump system for buildings. Energy and Buildings. 2013. No. 65. P. 75-83.

9. Tsao J. Solar and wind hybrid powered air-conditioning/refrigeration, space-heating, hot water supply and electricity generation system. United States Patent No. US7937955B2, 2011. P. 1-41.

10. Haslach H. W. Jr. Wind turbine heating generating apparatus. United States Patent No. 4596209, 1986. P. 1-7.

11. Yeaple F. Fluid Power Design Handbook. CRC Press, 1995. $854 \mathrm{p}$.

12. Žiedelis S. Hidraulinès ir pneumatines sistemos. Kaunas, 2009. 196 p.

13. Thompson W. J., Freeman P. A. Wind-powered impeller-mixer. United States Patent No. 4292540, 1981. P. 1-6.

14. Maegaard P., Krenz A., Palz W. Wind Power for the World: The Rise of Modern Wind Energy. Pan Stanford Publishing, 2013. 676 p.

15. Hackett R. S. Heating system. United States Patent No. 3822740, 1974. P. 1-5.

16. Ozgener O. Use of solar assisted geothermal heat pump and small wind turbine systems for heating agricultural and residential buildings. Energy. 2010. No. 35. P. 262-268.

17. Kruopis J. Matematine statistika. Vilnius: Mokslas, $1993.416 \mathrm{p}$.

18. Саутин С. Н. Планирование эксперимента в химии и химической технологии. Ленинград „Химия“, 1975. 48 с. 
Jurgita Černeckienė, Tadas Ždankus

INVESTIGATION OF WIND ENERGY USAGE FOR THE HEATING WITH A HYDRAULIC

\section{SYSTEM}

Summary

Using wind energy for the heating of buildings can significantly reduce fuel consumption and thus environmental pollution. The issue of wind mechanical energy conversion into heat is not new, but now electrical systems, where a wind rotor drives an electric generator, and heat in the building is obtained by using electric heaters, are the most common. Larger amounts of generated heat and lower investment could be achieved by using a hydraulic heat generation system instead of an electric one.
The main components of a hydraulic system in the experimental research were a gear pump, a load control valve and a heat exchanger. A small wind turbine rotor work is experimentally modeled with electric motor rotating at up to $5 \mathrm{~Hz}$. The experimental studies have shown that the hydraulic heat generation system, even if unloaded, reaches the efficiency of up to 0.5 , and the load efficiency increases to $>0.85$. Heat generated by wind energy can be supplied to the coolant in an accumulation tank if the building uses a gas or solid fuel boiler as the main energy source. Otherwise, heat can be accumulated in the soil if a geothermal system is used for the heating of a building.

Key words: wind energy, hydraulic system, energy transformations, heat exchange, heating of the building 